\title{
Bacterial spot and early blight biocontrol by epiphytic bacteria in tomato plants
}

\author{
Roberto Lanna Filho(1), Reginaldo da Silva Romeiro(2) and Eduardo Alves(1)
}

(1)Universidade Federal de Lavras, Departamento de Fitopatologia, Caixa Postal 3037, CEP $37200-000$ Lavras, MG, Brazil. E-mail: robertolanna@yahoo.com.br, ealves@ufla.br ${ }^{(2)}$ In memoriam

\begin{abstract}
The objective of this work was to evaluate in vitro and in vivo biocontrol of bacterial spot (Xanthomonas vesicatoria) and early blight (Alternaria solani) by the epiphytic bacteria Paenibacillus macerans and Bacillus pumilus. Tomato plants were previously sprayed with epiphytic bacteria, benzalkonium chloride and PBS buffer and, after four days, they were inoculated with $A$. solani and $X$. vesicatoria. To determine the phytopathogenic bacteria population, leaflet samples were collected from each treatment every 24 hours, for seven days, and plated on semi-selective medium. The effect of epiphytic bacteria over phytopathogens was performed by the antibiosis test and antagonistic activity measured by inhibition zone diameter. The epiphytic and benzalkonium chloride drastically reduced the severity of early blight and bacterial spot in comparison to the control (PBS). In detached leaflets, the epiphytic bacteria reduced in $70 \%$ the number of phytopathogenic bacteria cells in the phylloplane. The antibiosis test showed that the epiphytic bacteria efficiently inhibit the phytopathogens growth. In all the bioassays, the epiphytic bacteria protect tomato plants against the phytopathogens.
\end{abstract}

Index terms: Alternaria solani, Bacillus pumilus, Paenibacillus macerans, Xanthomonas vesicatoria, biological control, epiphytic bacteria.

\section{Biocontrole da mancha-bacteriana e da pinta-preta por bactérias epifíticas em tomateiro}

\begin{abstract}
Resumo - O objetivo deste trabalho foi avaliar o biocontrole in vitro e in vivo dos fitopatógenos manchabacteriana (Xanthomonas vesicatoria) e pinta-preta (Alternaria solani) pelas bactérias epifíticas Paenibacillus macerans e Bacillus pumilus. Plantas de tomate foram previamente pulverizadas com as bactérias epifíticas, cloreto de benzalcônio e tampão PBS e, após quatro dias, receberam inoculação com $A$. solani e $X$. vesicatoria. A fim de determinar a população da bactéria fitopatogênica, amostras de folíolos foram coletadas de cada tratamento em intervalos de 24 horas, durante sete dias, e inoculadas em meio semisseletivo. O efeito das bactérias epifíticas sobre os fitopatógenos foi realizado pelo teste de antibiose e atividade antagônica avaliada pelo diâmetro da zona de inibição. As bactérias epifíticas e o cloreto de benzalcônico reduziram drasticamente a severidade da pinta-preta e da mancha-bacteriana, comparado com o controle (PBS). Em folíolos destacados, as bactérias epifíticas reduziram em até $70 \%$ o número de células da bactéria fitopatogênica no filoplano. As bactérias epifíticas inibem eficientemente o crescimento dos fitopatógenos em meio de cultura. Em todos os bioensaios, as bactérias epifíticas protegem as plantas de tomate contra os fitopatógenos.
\end{abstract}

Termos para indexação: Alternaria solani, Bacillus pumilus, Paenibacillus macerans, Xanthomonas vesicatoria, controle biológico, bactéria epifítica.

\section{Introduction}

Epiphytic bacteria have been defined as populations that can survive and multiply on the surface of plants (Hirano et al., 1982). Thus, they develop survival strategies in protected positions such as the trichomes base, inside substomatal chambers, hydathodes, and, especially, in between the depressions along the junctions of adjacent epithelial cells (Beattie \&
Lindow, 1999; Lindow \& Brandl, 2003; Monier \& Lindow, 2004, 2005a, 2005b).

Epiphytics as biological control agents are still misused, especially compared to rhizobacteria and endophytic bacteria. However, the biocontrol of diseases affecting several crops by those microorganisms have been increasingly researched (Lindow \& Brandl, 2003; Halfeld-Vieira et al., 2008). Notably, the interest in the study of those microbes is related to their capacity to

Pesq. agropec. bras., Brasília, v.45, n.12, p.1381-1387, dez. 2010 
occupy ecological niches on the phylloplane that could be occupied by pathogens (Monier \& Lindow, 2005a), and to their broad antagonistic effect against pathogens. Biosurfactants, antibiotics, bacteriocins and volatile organic compounds (VOCs) synthesis, siderophores and competition for space and nutrients are related to the antagonistic effects of epiphytic bacteria on the phytopathogen growth (Beattie \& Lindow, 1999; Lindow \& Brandl, 2003). Recent surveys demonstrate that epiphytic bacteria also act as elicitors of the induced systemic resistance (ISR) in plants (Halfeld-Vieira et al., 2006).

The objective of this work was to evaluate in vitro and in vivo biocontrol of bacterial spot (Xanthomonas vesicatoria) and early blight (Alternaria solani) by the epiphytic bacteria Paenibacillus macerans and Bacillus pumilus.

\section{Materials and Methods}

Two epiphytic bacteria were obtained from leaves of healthy tomato plants, and identified by fatty-acid analysis (FAA) (Lanna Filho, 2006) as Paenibacillus macerans and Bacillus pumilus. Afterward, bacteria were grown in medium 523 (Kado \& Heskett, 1970) [10 $\mathrm{g} \mathrm{L}^{-1}$ of sucrose, $8 \mathrm{~g} \mathrm{~L}^{-1}$ of casein acid hydrolysate, $4 \mathrm{~g} \mathrm{~L}^{-1}$ of yeast extract, $2 \mathrm{~g} \mathrm{~L}^{-1}$ of $\mathrm{K}_{2} \mathrm{HPO}_{4}$ (anhydrous), $0,3 \mathrm{~g} \mathrm{~L}^{-1}$ of $\mathrm{MgSO}_{4} \cdot 7 \mathrm{H}_{2} \mathrm{O}$ and $18 \mathrm{~g} \mathrm{~L}^{-1}$ of agar], and preserved in deep freezer at $-80^{\circ} \mathrm{C}$. They were also emulsified once in $30 \%(\mathrm{v} / \mathrm{v})$ glycerin.

The tomato pathogens were obtained from the Plant Pathology Department collection of the Universidade Federal de Viçosa, Brazil. The fungus Alternaria solani (Jones \& Grout) was grown in potato dextrose agar (PDA) and maintained at $4^{\circ} \mathrm{C}$ under mineral oil (Smith \& Onions, 1994). The bacterium Xanthomonas vesicatoria (Doidge) Vauterin et al. was grown in medium 523 (Kado \& Heskett, 1970), preserved at $-80^{\circ} \mathrm{C}$, and emulsified once in $30 \%$ glycerin.

The antagonistic activity was tested by the overlay diffusion method (Vidaver et al., 1972). A drop of $15 \mu \mathrm{L}$ of cell suspension (optical density at $540 \mathrm{~nm}$ wavelength, $\mathrm{OD}_{540}=0.3$ ) of the $P$. macerans and B. pumilus epiphytic bacteria was placed in the center of the solid medium 523 (Kado \& Heskett, 1970), in Petri dishes, and incubated at $28^{\circ} \mathrm{C}$ for 24 hours. As control, a drop of $15 \mu \mathrm{L}$ of phosphate-buffered saline (PBS) was placed in the center of the solid medium of the same culture.

Subsequently, the colonies were killed by exposure to ultraviolet (UV) and chloroform vapors for 1 hour. Then, melted semisolid culture media $[0.8 \%(\mathrm{w} / \mathrm{v})$ agar, $45^{\circ} \mathrm{C}$ ] containing propagules of the pathogens was placed over the basal layer, and incubated at $28^{\circ} \mathrm{C}$ for 24 hours (X. vesicatoria) and at $25^{\circ} \mathrm{C}$ for seven days ( $A$. solani). After incubation, the inhibition zones were measured and antimicrobial activity was expressed by the diameter of the inhibition zone ( $\mathrm{mm})$. The percentage of the inhibition zone was calculated in relation to the diameter of the Petri dish $(90 \mathrm{~mm})$, considered $100 \%$. The bioassay was repeated three times for each treatment (P. macerans, B. pumilus and PBS), and three zones of inhibition were measured for each epiphytic bacterium.

The epiphytics were observed on phylloplane by scanning electron microscopy. For that, seeds of Santa Cruz 'Kada' tomato were disinfected in $70 \%$ ethanol for $2 \mathrm{~min}$, sodium hypochlorite solution ( $2 \%$ available $\mathrm{Cl}^{-}$) for $2 \mathrm{~min}$, and two washes were carried out in sterilized distilled water. Then, they were transferred to $20 \mathrm{~mL}$ plastic cups with the epiphytic bacteria cell suspensions, adjusted to $\mathrm{OD}_{540}=0.3$, corresponding to approximately $10^{8}$ colony forming units per $\mathrm{mL}\left(\mathrm{CFU} \mathrm{mL} \mathrm{mL}^{-1}\right)$. Cell suspension volume was only sufficient to cover the seeds. After 24 hours, seeds were placed on filter paper for drying. Seeds immersed only in PBS (1 mol L-1; pH 7.0) were used as controls. After drying, seeds were transferred to three tubes containing MS medium per treatment (Murashige \& Skoog, 1962), and germinated at $25^{\circ} \mathrm{C}$ with 12-hours photoperiod. In fifteen-day-old plants, three leaves per treatment were cut, and submitted to a fixative procedure in a modified Karnovsky solution (glutaraldehyde $2.5 \%$ and paraformaldehyde $2.5 \%$ in sodium cacodylate buffer $0.05 \mathrm{~mol} \mathrm{~L}^{-1}, \mathrm{pH} \mathrm{7.2,} \mathrm{CaCl}_{2}$ $0.001 \mathrm{~mol} \mathrm{~L}^{-1}$ ), for 24 hours $\left(\right.$ at $4^{\circ} \mathrm{C}$ ), infiltrated with a cryoprotection solution (glycerol $30 \%$ in water) for $30 \mathrm{~min}$, and cross-sectioned with a scalpel blade after being immersed in liquid nitrogen.

Sections were transferred to a $1 \%$ aqueous solution of osmium tetroxide for 1 hour at room temperature, and subsequently dehydrated for $10 \mathrm{~min}$ each in a crescent series of acetone solutions $(25,50,75,90$ and $100 \%$ ). After that, they were dried in a critical-point drier CPD 030, (Balzers, Jundiaí, SP, Brazil). 
Processed materials were mounted on aluminum stubs, fractured side up, sputter coated with gold SCD 050, (Balzers, Jundiaí, SP, Brazil) and observed in a scanning electron microscopy (SEM) LEO EVO 40 XVP (K. E. Developments, Cambridge, England). Leaves of healthy tomato plants exposed to PBS were used as controls. Two images were generated and three leaflets were used for each treatment. Images of the phylloplane region were generated at random for each sample, at several magnifications, and digitally recorded. Images were processed using the software Corel Draw 12, with which comparisons among treatments were done.

The antagonistic effect of the epiphytic bacteria over the phytopathogenic one was carried out in twenty-day-old tomato plants, previously exposed to the $P$. macerans, B. pumilus, benzalkonium chloride and PBS treatments. After four days, the $X$. vesicatoria suspension $\left(\mathrm{OD}_{540}=0.3\right)$ was sprayed. For each treatment, four replicates were used; with three grams of leaves per pot being considered as one replicate. Leaves were collected randomly and placed in flasks containing $50 \mathrm{~mL}$ of sterile phosphate buffer $\left(0.1 \mathrm{~mol}^{-1}, \mathrm{pH} 7.0\right.$, containing $0.05 \%$ Tween-80), and sonicated for $10 \mathrm{~min}$ in an ultrasonic cleaning bath (Ultrasonic Cleaner 1440D, Odontobrás, Ribeirão Preto, SP, Brazil) in order to recover bacterial cells. Bacterial populations were estimated from three grams symptomless leaflets randomly sampled from each plant pot. The obtained suspensions of washed leaves were submitted to serial dilution (factor $=1: 1,000)$ and were inoculated in the semi-selective medium propose by Lanna Filho \& Romeiro (2009), containing cycloheximide $\left(50 \mu \mathrm{g} \mathrm{mL}^{-1}\right)$, cephalexin $\left(50 \mu \mathrm{g} \mathrm{mL}^{-1}\right)$ and streptomycin sulfate $\left(50 \mu \mathrm{g} \mathrm{mL} \mathrm{m}^{-1}\right)$. Petri dishes were incubated for 48 hours at $28^{\circ} \mathrm{C}$, and then the CFU count was made per gram of leaf tissue. The leaf samples were collected every 24 hours, for seven days. For each evaluation day, three Petri dishes were used for each dilution, with three replicates per dishes. The mean viable bacterial population size was derived from the $\log _{10}$-transformed bacterial population.

In greenhouse experiments, seeds of Santa Cruz 'Kada' tomato were planted in plastic pots containing non-sterilized mixture of soil, sand and manure (2:1:1), maintained in greenhouse at $25^{\circ} \mathrm{C}$ and $70 \%$ relative humidity. In each treatment, four replicates were used, with one plant per pot considered as a replicate. Plants were sprayed with live cells of the P. macerans and B. pumilus $\left(\mathrm{OD}_{540}=0.3\right) 30$ days after planting. For the positive control, plants were sprayed with benzalkonium chloride sanitizer $(2.5 \mathrm{~g}$ $\mathrm{L}^{-1}$ a.i.), and PBS as negative control. Four days later, plants were inoculated spraying the $A$. solani $(1.0 \times$ $10^{5}$ conidia $\left.\mathrm{mL}^{-1}\right)$ and $X$. vesicatoria $\left(\mathrm{OD}_{540}=0.3\right)$ pathogen suspensions. Inoculated plants were kept in greenhouse, and after the symptoms of the disease were fully developed, the number of lesions per leaf was counted within all the leaflets. The bioassay was repeated three times.

All experiments were carried out in a completely randomized design. The results were subjected to analysis of variance (ANOVA) and means were compared by Tukey test at 5\% probability, using the software Statistica, version 7.0 (Statsoft, 2005). Regression equations, coefficient of determination $\left(\mathrm{R}^{2}\right)$ and significance levels of the curves were calculated in order to determine the bacterial population growth according to time.

\section{Results and Discussion}

The in vitro antibiosis test showed that the epiphytic bacteria presented direct activity against the pathogens $X$. vesicatoria and $A$. solani, inhibiting their growth (Table 1). Paenibacillus macerans and B. pumilus inhibited $X$. vesicatoria growth at 10.33 and $8.67 \%$, respectively, and $A$. solani growth at 3.11 and $4.89 \%$. Additionally, the control treatment with PBS showed no zone of inhibition ( $0 \%$ ) against the pathogens. These results confirmed that the antagonists produce some type of toxic substance with antimicrobial effect against the pathogens, causing the antibiosis phenomenon.

Possibly, these substances are bioactive compounds derived from lipopeptides of the surfactin, iturin and

Table 1. In vitro antimicrobial activity of Paenibacillus macerans and Bacillus pumilus against tomato pathogens ${ }^{(1)}$.

\begin{tabular}{lccc}
\hline Pathogen & \multicolumn{3}{c}{ Growth inhibition (\%) } \\
\cline { 2 - 4 } & B. pumilus & P. macerans & Control $^{(2)}$ \\
\hline Xanthomonas vesicatoria & $8.67 \mathrm{a}$ & $10.33 \mathrm{a}$ & $0.00 \mathrm{~b}$ \\
Alternaria solani & $4.89 \mathrm{a}$ & $3.11 \mathrm{a}$ & $0.00 \mathrm{~b}$ \\
\hline
\end{tabular}

(1)Means followed by the same letter, in the lines, do not differ by Tukey's test at 5\% probability. ${ }^{(2)}$ Phosphate-buffered saline (PBS). 
fengycin families, frequently reported as toxic to pathogens (Peypoux et al., 1999; Ongena et al., 2005). Magnet-Dana et al. (1992) reported that the iturins and fengycins exhibit a strong antifungal activity and are inhibitory for the growth of a wide range of pathogens. Additionally, the synthesis of antimicrobials by epiphytic bacteria provides higher adaptability of those microbes on the phylloplane, impeding the growth and establishment of pathogenic populations (Beattie \& Lindow, 1999).

The observation of the colonization pattern of the epiphytic bacteria on the phylloplane by SEM confirmed their ability in establishing at specific sites on the foliar surface (Figure 1). This demonstrates the capacity of these bacteria to migrate from spermosphere to the aerial part, their habitat. Notably, the formation of $P$. macerans cell aggregates embedded in an exopolymeric matrix could be observed in the depressions along the junctions of adjacent epithelial cells (Figure $1 \mathrm{~A}$ ), besides the colonization of the stomatal region (Figure $1 \mathrm{~B}$ ). Numerous studies report the capacity of epiphytic bacteria to form aggregates on the foliar surface of different species of plants (Morris et al., 1997; Fett, 2000), which gives them protection against environmental stress and larger survival on the phylloplane, as reported by Monier \& Lindow (2004). Bacillus pumilus also formed small aggregates between the depressions along the junctions of adjacent epithelial cells (Figure 1 C), as well as in the stomatal region (Figure 1 D). As expected, the treatment with phosphate-buffered saline did not present bacterial colonization (Figures $1 \mathrm{E}$ and F). Monier \& Lindow (2005a, 2005b) report the importance of the aggregate formation for the protection of epiphytic population against desiccation, UV radiation, high temperatures and environmental fluctuations, besides the higher efficiency in nutrient acquisition and migration to regions of the phylloplane more favorable for survival. This work demonstrated that bacterial cells of $P$. macerans and B. pumilus form large aggregates on the tomato phylloplane. This confirms the natural habitat of these bacteria, since both were exposed to previously disinfested seeds and, after 15 days of germination, they were established at specific sites on the foliar surface.

Tomato leaves previously exposed to the epiphytic bacteria and to benzalkonium chloride drastically reduced the $X$. vesicatoria population on the phylloplane, in comparison with the control, treated with PBS (Figure 2). The sanitizer (benzalkonium chloride) reduced the pathogen population on the phylloplane by $80.4 \%$, while the antagonists P. macerans and B. pumilus reduced it by 68 and $70 \%$, respectively, compared to PBS. These results confirm the antibacterial activity of the sanitizer against the phytobacteria, which was already expected, since quaternary ammonium based compounds possess fungicidal, bactericidal, algicidal and virucidal action (Mcbain et al., 2004; Oosterhof et al., 2006; Abreu et al., 2008). The antagonists probably acted on the reduction of the pathogen population by multiple mechanisms, such as competition for space and nutrients, antibiosis, and, possibly, resistance induction (Lindow \& Brandl, 2003; Monier \& Lindow, 2004, 2005ab; Halfeld-Vieira et al., 2006).

Although ISR has not been investigated in this research, Halfeld-Vieira et al. (2006) relate the phenomenon for the epiphytic Bacillus cereus in tomato plants, which controlled the bacterium Pseudomonas syringae pv. tomato. Besides ISR, synthesis of antimicrobial compounds and competition for niches important to pathogen establishment are reported by Lindow \& Brandl (2003) as one of the most important mechanisms for antagonistic effect on the foliar surface. Leveau \& Lindow (2001) reported efficient use of nutrients by epiphytics as an important mechanism for the antagonistic activity.

Effective control of bacterial spot and early blight was observed in the greenhouse bioassay, in the treatments using $P$. macerans, B. pumilus and benzalkonium chloride (Figure 3). The epiphytics and the sanitizer differed from the control treatment, reducing the severity by over $50 \%$ in some cases. These results demonstrate the use potential of those biocontrol agents against two important tomato diseases. Halfeld-Vieira et al. (2008) proved the efficiency of the epiphyte Bacillus cereus UFV-IEA6 against Phytophthora infestans.

Recent studies have shown the effectiveness of phylloplane residents in controlling several pathogens (Vasudevan et al., 2002; Velusamy \& Gnanamanickam, 2003; Velusamy et al., 2004). Gnanamanickam \& Immanuel (2006) report the importance of the study of these microbes in plant disease control, stressing the main species of Bacillus currently studied. However, 

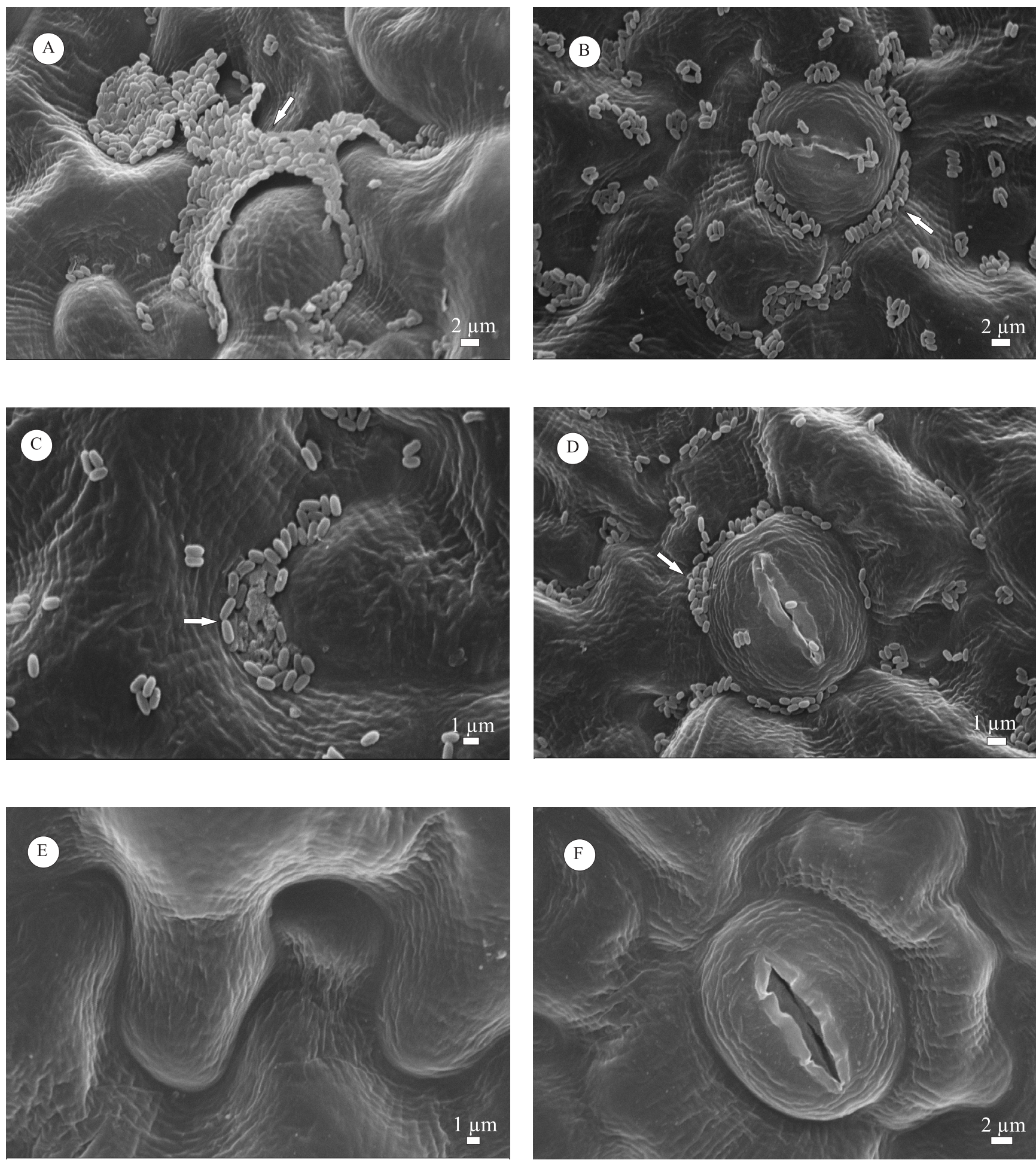

Figure 1. Scanning electromicrographs of tomato leaves grown from seeds treated with the epiphytic bacteria Paenibacillus macerans and Bacillus pumilus, compared with the control (phosphate-buffered saline). A, P. macerans aggregates in the depressions along the junctions of adjacent epithelial cells; B, P. macerans small aggregate formation at the stomatal region; $\mathrm{C}$, B. pumilus aggregates in the depressions along the junctions of adjacent epithelial cells; D, B. pumilus aggregate formation at the estomatal region and in the depressions along the junctions of adjacent epithelial cells. E and F represent the control treatments. 


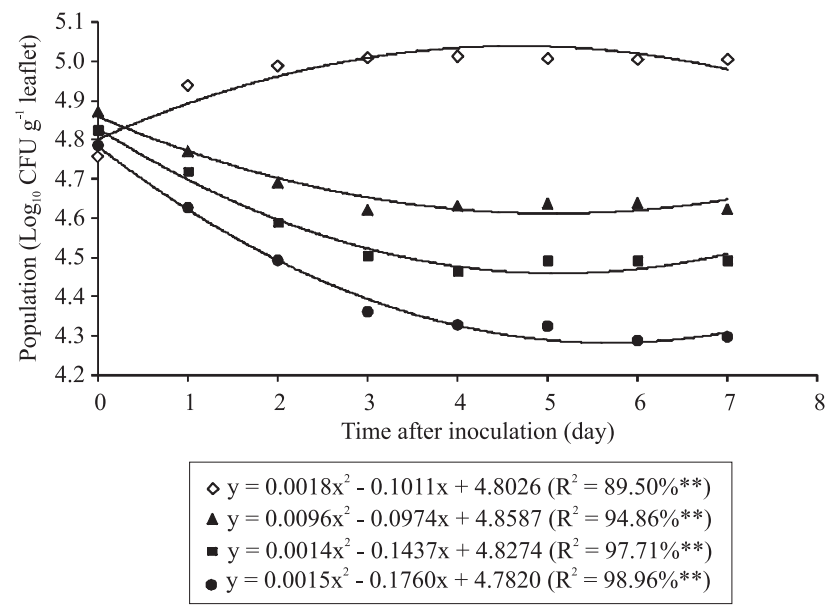

Figure 2. Population dynamics of plant pathogenic bacterium Xanthomonas vesicatoria ( $\log _{10} \mathrm{CFU} \mathrm{g} \mathrm{g}^{-1}$ leaflet) on tomato leaves after prior exposure to treatments with Paenibacillus macerans ( $(\mathbf{\Delta})$, Bacillus pumilus $(\boldsymbol{\square})$, benzalkonium chloride $(\mathrm{BC})(\bullet)$ and PBS buffer (control) $(\diamond)$. Each point indicates the mean of the $\log _{10}$-transformed bacterial population.
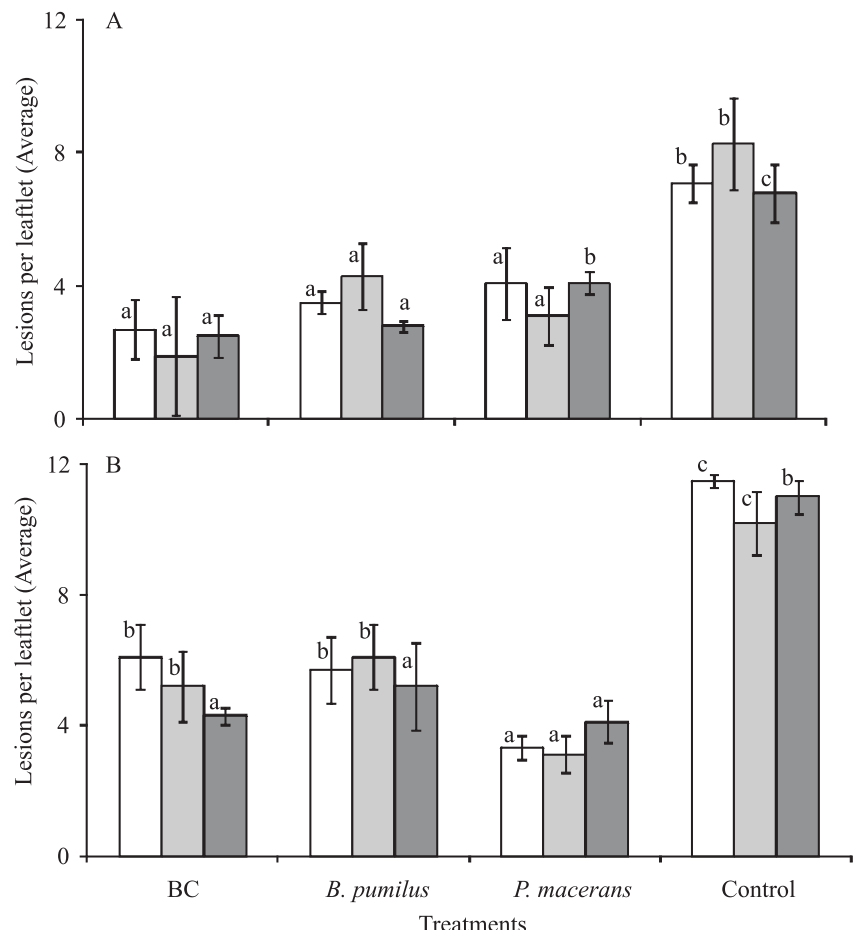

Figure 3. Severity of bacterial spot (A), and early blight (B), in Santa Cruz 'Kada' tomato plants, four days after exposure to treatments with Bacillus pumilus, Paenibacillus macerans, benzalkonium chloride (BC) and PBS buffer (control). The white, light grey, and dark grey bars represent the experiment replicates. Means followed by same letter do not differ by the Tukey's test, at $5 \%$ probability. in Brazil, few researches report the importance of epiphytic bacteria to control diseases.

\section{Conclusions}

1. Paenibacillus macerans and Bacillus pumilus epiphytic bacteria and benzalkonium chloride reduce Xanthomonas vesicatoria and Alternaria solani disease severity in tomato plants.

2. Epiphytic bacteria are able to inhibit the growth of tested phytopathogens in vitro, and efficiently colonize the phylloplane of tomato plants.

\section{Acknowledgments}

To Fundação de Amparo à Pesquisa de Minas Gerais (Fapemig), for financial support; and to the Laboratório de Microscopia Eletrônica e Análise Ultraestrutural of the Universidade Federal de Lavras, for the scanning electron microscopy analysis.

\section{References}

ABREU, F.M. de; LOURENÇO, S.A.; BASSETTO, E.; GONÇALVES, F.P.; MARTINS, M.C.; AMORIM, L. Efeito de sanificantes no controle pós-colheita da podridão parda (Monilinia fructicola) e da podridão mole (Rhizopus stolonifer) em pêssegos. Summa Phytopathologica, v.34, p.86-88, 2008.

BEATTIE, G.A.; LINDOW, S.E. Bacterial colonization of leaves: a spectrum of strategies. Phytopathology, v.89, p.353-359, 1999.

FETT, W.F. Naturally occurring biofilms on alfalfa and other types of sprouts. Journal of Food Protection, v.63, p.625-632, 2000.

GNANAMANICKAM, S.S.; IMMANUEL, J.E. Epiphytic bacteria, their ecology and functions. In: GNANAMANICKAM, S.S. (Ed.). Plant-associated bacteria. Dordrecht: Springer, 2006. p.131-154.

HALFELD-VIEIRA, B. de A.; ROMEIRO, R. da S.; MOUNTEER, A.; MIZUBUTI, E.S.G. Efficiency of phylloplane bacteria in controlling aerial tomato diseases under field conditions. Summa Phytopathologica, v.34, p.86-87, 2008.

HALFELD-VIEIRA, B. de A.; VIEIRA JÚNIOR, J.R.; ROMEIRO, R. da S.; SILVA, H.S.A.; BARACAT-PEREIRA, M.C. Induction of systemic resistance in tomato by the autochthonous phylloplane resident Bacillus cereus. Pesquisa Agropecuária Brasileira, v.41, p.1247-1252, 2006.

HIRANO, S.S.; NORDHEIM, M.E.V.; ARNY, D.C.; UPPER, C.D. Lognormal distribution of epiphytic bacterial populations on leaf surfaces. Applied and Environmental Microbiology, v.44, p.695-700, 1982.

KADO, C.I.; HESKETT, M.G. Selective media for isolation of Agrobacterium, Corynebacterium, Erwinia, Pseudomonas, and Xanthomonas. Phytopathology, v.60, p.969-976, 1970. 
LANNA-FILHO, R. Isolamento e seleção de procariotos residentes de filoplano do tomateiro com potencial para 0 controle de doenças da cultura. 2006. 52p. Tese (Mestrado) Universidade Federal de Viçosa, Viçosa.

LANNA FILHO, R.; ROMEIRO, R. da S. Sensibilidade de Xanthomonas vesicatoria a antibióticos para desenvolvimento de um meio semi-seletivo. Revista Trópica: Ciências Agrárias e Biológicas, v.3, p.28-39, 2009.

LEVEAU, J.H.J.; LINDOW, S.E. Appetite of an epiphyte: quantitative monitoring of bacterial sugar consumption in the phyllosphere. Proceedings of the National Academy of Sciences of the United States of America, v.98, p.3446-3453, 2001.

LINDOW, S.E.; BRANDL, M.T. Microbiology of the phyllosphere. Applied and Environmental Microbiology, v.69, p.1875-1883, 2003.

MAGNET-DANA, R.; THIMON, L.; PEYPOUX, F.; PTAK, M. Surfactin/iturin A interactions may explain the synergistic effect of surfactin on the biological properties of iturin A. Biochimie, v.74, p.1047-1051, 1992.

MCBAIN, A.J.; LEDDER, R.G.; MOORE, L.E.; CATRENICH, C.E.; GILBERT, P. Effects of quaternary-ammonium-based formulations on bacterial community dynamics and antimicrobial susceptibility. Applied and Environmental Microbiology, v.70, p.3449-3456, 2004.

MONIER, J.M.; LINDOW, S.E. Aggregates of resident bacteria facilitate survival of immigrant bacteria on leaf surfaces. Microbial Ecology, v.49, p.343-352, 2005a.

MONIER, J.M.; LINDOW, S.E. Frequency, size, and localization of bacterial aggregates on bean leaf surfaces. Applied and Environmental Microbiology, v.70, p.346-355, 2004.

MONIER, J.M.; LINDOW, S.E. Spatial organization of dual-species bacterial aggregates on leaf surfaces. Applied and Environmental Microbiology, v.71, p.5484-5493. 2005b.

MORRIS, C.E.; MONIER, J.M.; JACQUES, M. Methods for observing microbial biofilms directly on leaf surfaces and recovering them for isolation of culturable microorganisms. Applied and Environmental Microbiology, v.63, p.1570-1576, 1997.

MURASHIGE, T.; SKOOG, F. A revised medium for rapid growth and bioassays with tobacco tissue cultures. Physiology Plant, v.15, 473-497, 1962.
ONGENA, M.; DUBY, F.; JOURDAN, E.; BEAUDRY, T.; JADIN, V.; DOMMES, J.; THONART, P. Bacillus subtilis M4 decreases plant susceptibility towards fungal pathogens by increasing host resistance associated with differential gene expression. Applied Microbiology and Biotechnology, v.67, p. 692-698, 2005.

OOSTERHOF, J.J.H.; BUIJSSEN, K.J.D.A.; BUSSCHER, H.J.; LAAN, B.F.A.M. van der; MEI, H.C. van der. Effects of quaternary ammonium silane coatings on mixed fungal and bacterial biofilms on tracheoesophageal shunt prostheses. Applied and Environmental Microbiology, v.72, p.3673-3677, 2006.

PEYPOUX, F.; BONMATIN, J.M.; WALLACH, J. Recent trends in the biochemistry of surfactin. Applied Microbiology and Biotechnology, v.51, p.553-563, 1999.

SMITH, D.; ONIONS. A.H.S. The preservation and maintenance of living fungi. Surrey: International Mycological Institute, 1994. $122 \mathrm{p}$.

STATSOFT. Statistica for Windows: user's manual. Tulsa Oklahoma: Statsoft Incorporation, 2005. 293p. Disponível em: $<$ http://www.statsoft.com>. Acesso em: 23 jul. 2010.

VASUDEVAN, P.; KAVITHA, S.; PRIYADARISINI, S.B.; BABUJEE, L.; GNANAMANICKAM, S.S. Biological control of rice diseases. In: GNANAMANICKAM, S.S. (Ed.). Biological control of crop diseases. New York: Marcel Dekker, 2002. p.11-32.

VELUSAMY, P.; DEFAGO, G.; THOMASHOW, L.S.; GNANAMANICKAM. S.S. Role of 2,4-diacetylphloroglucinol (DAPG) for plant disease control: its importance to rice bacterial blight suppression in India. In: MAYEE, C.D.; MANOHARACHARY, C.; TILAK, K.V.B.R.; MUKADAM, D.S.; DESHPANDE, J. (Ed.). Biotechnological approaches for the integrated management of crop diseases. New Delhi: Daya Publishing House, 2004. p.182-191.

VELUSAMY, P.; GNANAMANICKAM, S.S. Identification of 2,4-diacetylphloroglucinol production by plant-associated bacteria and its role in suppression of rice bacterial blight in India. Current Science, v.85, p.1270-1273, 2003.

VIDAVER, A.K.; MATHYS, M.L.; THOMAS, M.E.; SCHUSTER, M.L. Bacteriocins of the phytopathogens Pseudomonas syringae pv. glycinea and Pseudomonas phaseolicola. Canadian Journal of Microbiology, v.18, p.705-713, 1972.

Received on August 12, 2010 and accepted on November 8, 2010 